\title{
Correlation Coefficient and Path Analysis Study in Different Soybean Genotypes Based on Yield and Yield Contributing Traits
}

\author{
M. G. Pawar*, S. B. Chaudhary, V. S. Pawar and S. B. Chavan \\ Department of Agricultural Botany, M.P.K.V., Rahuri (Maharashtra), India \\ *Corresponding author
}

\begin{abstract}
A B S T R A C T
The present investigation entitled Study of Correlation coefficient and path analysis in Different Soybean Genotypes Based on Yield and Yield Contributing Traits was undertaken to study the interrelation between variables means correlation and path analysis among thirty genotypes of soybean. These genotypes were evaluated during Kharif, 2018 in a randomized block design with three replications. Observations were recorded on days to 50 percent flowering, days to maturity, plant height $(\mathrm{cm})$, number of primary branches per plant, number of pods per plant, number of seeds per pod, 100 seed weight (g), seed yield per plant $(\mathrm{g})$, SPAD value, protein content $(\%)$, oil content $(\%)$. The genotypic correlation coefficients were high in magnitude than their corresponding phenotypic correlation coefficients for all the characters. The seed yield per plant showed a highly significant positive association with number of pods per plant, number of seeds per pod, 100 seed weight, SPAD value, plant height, days to 50 percent flowering, oil content, number of primary branches per plant and 50 percent flowering at genotypic level. Path coefficient analysis based on genotypic correlation indicate that number of pod per plant (0.5291) registered the maximum positive direct effect on seed yield per plant followed by 100 seed weight $(0.4061)$, number of seeds per pod (0.2882), plant height $(0.2111)$ and days to 50 percent flowering recorded the highest negative direct effect of -0.3126 followed by SPAD value -0.0827 , days to maturity -0.0155 . The number of primary branches per plant recorded the direct effect but low magnitude (0.0080).
\end{abstract}

Keywords

Soybean,

Correlation,

Path coefficient,

Traits, Yield

Article Info

Accepted:

07 August 2020

Available Online:

10 September 2020

\section{Introduction}

Soybean (Glycine $\max$ L. Merril) is considered a miracle crop due to its extraordinary qualities. It is grown in East and South East Asia mainly for food, feed, and medicinal purposes. This plant contains about $38-42 \%$ of high-quality protein, $6 \%$ ash, $29 \%$ carbohydrate, and 17 to $24 \%$ oil, comprising
$85 \%$ polyunsaturated fatty acids with two essential fatty acids. Soybean $(2 n=40)$ belongs to the Leguminosae family and is believed to have originated in northeastern China and distributed in the USA, Brazil, Argentina, China, India, etc.

Today it ranks first in oilseed production (contribution $58 \%$ ) followed by rapeseed, 
groundnut, and sunflower. In India, it occupied an area of 10.97 mha with a production of $13.46 \mathrm{mt}$ and a productivity of $1120 \mathrm{~kg} \mathrm{ha}^{-1}$ (Anonymous, 2018-19).

In India, major soybean-producing states are Madhya Pradesh, Maharashtra, Rajasthan, Karnataka, Gujarat, Andhra Pradesh Uttar Pradesh and Chhattisgarh.

The continuous improvement of soybean depends on the information about genetic variability, genetic parameters, and their application, that assists the breeders in the reliable selection process.

Yield is a complex polygenic character, resulting from multiple interactions between many yield-contributing traits. Associations between these traits can be evaluated by correlation analysis, which helps in the simultaneous selection for more than one character.

Correlation coefficients alone are inadequate to interpret cause and effect relationships among traits associated with yield, whereas path coefficient analysis allows a better understanding of associations between different characters, by breaking down correlation coefficients associated with the main character into direct and indirect effects (Rahman et al., 2011, 2012; Hossain et al., 2015).

Path coefficient analysis provides an effective means to partition correlation coefficients into unidirectional and alternative pathways, thus permitting a critical examination of the specific factors that produce a given correlation; this can then be employed to formulate an effective selection program.

This investigation provides information that could lead to the development of desirable genotypes in future breeding programs.

\section{Materials and Methods}

To study 30 different soybean genotypes collected from Agricultural Research Station, Kasbe-Digraj, Sangli (Table 1).

\section{Experimental methods}

\section{Field experiment}

The field experiment consisting of 30 soybean genotypes was undertaken at Agricultural Research Station, Kasbe-Digraj, Sangli. To study recommended agronomic practices were followed to raise good crops. The detail of the experiment is as follows.
a) Season - Kharif, 2018
b) Design - RBD (Randomized Block Design)
c) Plot size - 5 X 2 meter
d) Date of sowing - 12 July 2018
e) Spacing - $45 \times 5 \mathrm{~cm}$
f) Number of genotypes -30
g) Fertilizer Dose - 30: 60:30 Kg NPK/ha

\section{Details of observations Recorded}

Following observations on the five randomly selected plants from each experimental plot in each replication and averages were worked out viz., days to 50 percent flowering, days to maturity, plant height $(\mathrm{cm})$, number of primary branches per plant, number of pods per plant, number of seeds per pod, 100 seed weight (g), seed yield per plant (g), SPAD value, protein content $(\%)$, oil content $(\%)$.

\section{Results and Discussion}

\section{Correlation coefficient}

The genotypic and phenotypic correlation for eleven characters studied is presented in Table 2. As the genotypic correlation as well as phenotypic correlation important from a 
breeding point of view, those only are described below:

Association between seed yield and its components

The seed yield per plant showed a highly significant and positive association with number of pods per plant $(0.54)$, followed by number of seeds per pod (0.43), 100 seed weight (0.41), SPAD value (0.37), plant height (0.33), days to $50 \%$ flowering (0.27), oil content (0.140). The character number of primary branches per plant (0.04) showed a positive but non-significant association with seed yield per plant. The character days to maturity (-0.06) and protein content $(-0.02)$ are negative and non-significant association with seed yield per plant.

Exactly similar trend was observed at the phenotypic level, where seed yield per plant recorded the highly significant and positive association with number of pods per plant (0.51), followed by the number of seeds per pod (0.39), 100 seed weight (0.35), SPAD value $(0.32)$, plant height $(0.31)$, days to $50 \%$ flowering (0.27). The characters number of primary branches per plant $(0.02)$ and oil content (0.01), protein content (0.001), showed positive but non- significant association with seed yield per plant. Days to maturity $(-0.06)$ showed negative and nonsignificant association seed yield per plant. These results confirmed the earlier findings of Faisal et al., (2006), Shahu et al., (2013), Ghodrati et al., (2013) and Chandel et al., (2014) reported the seed yield per plant was highly significant and positively correlated with number of pods per plant. Malek et al., (2014) and Ali et al., (2015) found seed yield per plant showed highly significant and positively correlated with days to 50 percent flowering, days to maturity. Mahbub et al., (2015) recorded the seed yield per plant revealed highly significant and positively correlated with the number of pods per plant, number of seeds per pod, 100 seed weight, and plant height. Koraddi et al., (2013) estimated seed yield per plant showed highly significant and positively correlated with days to 50 percent flowering, number of pods per plant, 100 seed weight.

\section{The interrelationship between yield components}

The interrelationship between component characters at the genotypic level is presented below:

\section{Genotypic correlations}

Days to 50\% flowering was highly significant and positively correlated with oil content (0.81)followed by plant height (0.77), days to maturity (0.73), number of seeds per pod $(0.50), 100$ seed weight $(0.36)$, seed yield per plant (0.27), SPAD value(0.22), number of pod per plant $(0.17)$. It showed a negative and non-significant correlation with protein content $(-0.08)$, number of primary branches per plant $(-0.08)$.

A similar result was reported by Aditya et al., (2011), Mahbub and shirazy (2016), and Dubey et al., (2014) for plant height.

Days to maturity was highly significant and positively correlated with oil content (1.08) followed by plant height (0.41), number of seeds per pod (0.31), number of primary branches per plant (0.15), It showed positive but non-significant correlation with SPAD Value (0.06) and 100 seed weight (0.02). Days to maturity were non-significant and negatively correlated with protein content ($0.001)$, seed yield per plant $(-0.06)$ and it showed a negative but significant correlation with the number of pods per plant (-0.14). A similar result was reported by Iqbal et al., (2010), Dubey et al., (2014), and Malek et al., 
(2014) for the height of plant and number of primary branches per plant.

Plant height showed a significant and positive correlation with oil content $(0.50)$ followed by 100 seed weight $(0.35)$, number of seeds per pod and seed yield per plant (0.33), SPAD value $(0.20$, ) number of pods per plant $(0.19)$ and number of primary branches (0.13). It was negatively and non-significantly correlated with protein content (-0.10). Similar results reported by Dubey et al., (2014) and Mahbub and Shirazy (2016) for the number of pods per plant.

The number of primary branches per plant was positive and significantly correlated with SPAD value (0.24) and the number of pods per plant (0.17). It showed a positive but nonsignificant correlation with protein content (0.05) and seed yield per plant (0.04). It showed a negative and non-significant correlation with oil content (-0.004), 100 seed weight (-0.09) and it showed a negative but significant correlation number of seeds per pod (-0.15). A similar result was reported by Jain and Ramgiry (2000) for the number of pods per plant.

The number of pods per plant showed a highly significant and positive correlation with seed yield per plant (0.54) followed by SPAD value (0.49) and the number of seeds per pod (0.30). Whereas it showed a positive and significant correlation with protein content (0.07) and oil content (0.01). It showed a negative and non-significant correlation with100 seed weight (-0.03). Similar results were reported by Ghodrati et al., (2013) and Khan et al., (2018) for seed yield per plant.

The character number of seeds per pod had a highly significant and positive correlation with seed yield per plant (0.43) followed by oil content (0.43), SPAD value, (0.30), and
100 seed weight (0.19). It had a positive but non-significant correlation with and protein content (0.06). A similar result was reported by Dubey et al., (2014) and Mahbub and Shirazy (2016) for seed yield per plant. In case of 100 seed weight had a positive and highly significant correlation with oil content (0.54) followed by seed yield per plant (0.41), SPAD value (0.26) and protein content (0.001). Similar results were reported by Mahbub and Shirazy (2016) for seed yield per plant.

The physiological character SPAD value showed a highly significant and positive correlation with oil content (0.68) followed by seed yield per plant (0.37) and protein content (0.14). The Protein content showed a positive and significant correlation with oil content (0.50). The association of protein content with seed yield per plant was negative and nonsignificant (-0.02). Oil content had a positive and significant association with seed yield per plant $(0.14)$ at the genotypic level.

\section{Phenotypic correlation}

Days to $50 \%$ flowering was highly significant and positively correlated with plant height (0.72) followed by days to maturity (0.68), number of seeds per pod (0.48), 100 seed weight (0.33), seed yield per plant $(0.27)$, oil content (0.26), SPAD value(0.17), number of pod per plant (0.16). It showed a negative and non-significant correlation with the number of primary branches per plant (-0.04) and protein content (-0.09). Similar results were reported by Dubey et al (2014) for days to maturity, number of seeds per pod, and Malek et al., (2014) for days to maturity. Ngon et al., (2006) for 100 seed weight. Days to maturity was highly significant and positively correlated with plant height $(0.38)$, followed by oil content (0.33), number of seeds per pod (0.27), It showed positive but non-significant correlation with number of primary branches 
per plant (0.07), SPAD Value (0.05) protein content (0.02), Days to maturity was nonsignificant and negatively correlated with 100 seed weight(-0.006), seed yield per plant ($0.06)$ and it showed negative and significant correlation with number of pods per plant (0.13). Similar results reported by Kumar et al., (2014) for 100 seed weight, Khan et al., (2018) for seed yield per plant.

Plant height showed a significant and positive correlation with 100 seed weight (0.32), followed by seed yield per plant (0.31), number of seed per pod (0.29), number of pods per plant $(0.17)$, oil content $(0.16)$, SPAD value $(0.15)$ and it showed positive but non-significant correlation with number of primary branches (0.09). It showed negatively and non-significantly correlated with protein content (-0.03). Similar results reported by Dubey et al., (2014) for the number of seeds per pod, Aditya et al., (2011) number of pods per plant.

The number of primary branches per plant was significant and positively correlated with the number of pods per plant (0.13). and It showed positive but non-significant correlation with SPAD value (0.06), seed yield per plant (0.02) and It showed negative and non-significant correlation with oil content (-0.01), protein content (-0.02), 100 seed weight $(-0.05)$ and number of seeds per pod (-0.11).Similar results reported by Aditya et al., (2011) for the number of pods per plant and seed yield per plant.

The number of pods per plant showed a highly significant and positive correlation with seed yield per plant (0.51) followed by SPAD value (0.42) and the number of seeds per pod (0.27). Whereas, it showed positive and significant correlation with protein content (0.06) and It showed a negative and non-significant correlation with100 seed weight (-0.01) and oil content (-0.02). Similar results reported by Aditya et al., (2011) for seed yield per plant. Dubey et al., (2014) for 100 seed weight. The character number of seeds per pod had a highly significant and positive correlation with seed yield per plant (0.39) followed by SPAD value (0.24), 100 seed weight $(0.17)$ and it had a positive but non-significant correlation with oil content (0.11) and protein content (0.05). Similar results reported by Dubey et al., (2014) for seed yield per plant.

100 seed weight depicted highly significant and positive correlation with seed yield per plant (0.35), and SPAD value (0.24) and it showed positive but non-significant correlation with oil content $(0.12)$ followed by and protein content (0.03). Similar results reported by Aditya et al., (2011) for seed yield per plant.

The physiological character SPAD value showed a highly significant and positive correlation with seed yield per plant (0.32) and oil content (0.18). It showed positive but non-significant correlation protein content (0.06).

The Protein content showed a positive but non-significant correlation with seed yield per plant (0.001) and it showed a negative and non-significant correlation with oil content ($0.05)$. The association of oil content with seed yield per plant was positive but nonsignificant (0.01). Oil content had a positive and significant association at the phenotypic level. Similar findings were reported by Iqbal et al., (2010) for seed yield per plant.

In the present investigation, the genotypic correlation coefficients were high in magnitude than their corresponding phenotypic correlation coefficients for all the characters. The seed yield per plant showed a highly significant positive association with number of pods per plant, number of seeds 
per pod, 100 seed weight, SPAD value, plant height, days to $50 \%$ flowering, oil content, number of primary branches per plant and 50 $\%$ flowering at genotypic level. These results confirmed the earlier findings of Faisal et al., (2006), Ali et al., (2015), and Mahbub et al., (2015).

\section{Path analysis}

The direct and indirect effects of the studied characters on the seed yield per plant at genotypic levels are presented in Table 3 and Fig. 1.

\section{Direct effect}

Path coefficient analysis based on genotypic correlation indicates that the number of pods per plant (0.5291) registered the maximum positive direct effect seed yield per plant followed by 100 seed weight (0.4061), number of seeds per pod (0.2882), plant height (0.2111). Days to $50 \%$ flowering recorded the highest negative direct effect of -0.3126 followed by SPAD value -0.0827 , days to maturity -0.0155 . The number of primary branches per plant recorded the direct effect but low magnitude (0.0080). A similar finding was reported by Rajanna et al., (2000) and machikowa and Laosuwan (2011) for the number of pods per plant and 100 seed weight, Salimi and Moradi (2012) for 100 seed weight. Koraddi et al., (2013) and Balla and Ibrahim (2017) for the number of pods per plant and height of plant, Malek et al., (2014) for the number of pods per plant and 100 seed weight. Dubey et al., (2014) and Akram et al., (2016) for days to 50 percent flowering and days to maturity.

\section{Indirect effect}

\section{Days to $50 \%$ flowering}

Days to $50 \%$ flowering recorded the maximum positive indirect effect of $(0.0274)$ via the number of primary branches per plant. The maximum negative indirect effect of 0.0556 was seen via the number of pods per plant followed by SPAD value (-0.0693), 100 seed weight (-0.1154), number of seeds per pod (-0.1580), days to maturity (-0.2302), and plant height (-0.2431). Similar results were reported by Akram et al., (2016) for plant height, number of pods per plant, and 100 seed weight. Dubey et al., (2014) for the number of pods per plant.

\section{Days to maturity}

Days to maturity recorded the maximum positive indirect effect of (0.0022)via the number of pods per plant. The maximum negative indirect effect of was seen via 100 seed weight (-0.0004) followed by SPAD value $(-0.0010)$, number of primary branches per plant (-0.0024), number of seeds per pod $(-0.0049)$, plant height $(-0.0064)$ and days to $50 \%$ flowering (-0.0114).Similar results reported by Akram et al., (2016) for the number of pods per plant. Dubey et al., (2014) for the number of primary branches per plant and plant height.

\section{Height of plant}

The character height of plant recorded the maximum positive indirect effect of (0.1642) via days to 50 percent flowering followed by days to maturity (0.0866), 100 seed weight (0.0753), number of seeds per pod (0.0710), SPAD value (0.0424), number of pods per plant (0.0406), number of primary branches per plant (0.0275). Similar results were reported by Akram et al., (2016) for 100 seed weight. Dubey et al., (2014) for days to 50 percent flowering, days to maturity, number of seeds per pod.

\section{Number of primary branches per plant}

Primary branches per plant recorded the maximum positive indirect effect of (0.0020) 
via SPAD value, followed by the number of pods per plant (0.0014), days to maturity (0.0012), Plant height (0.0010).

The maximum negative indirect effect of (0.0007 ) was seen via days to $50 \%$ flowering and 100 seed weight followed by the number of seeds per pod (-0.0012). Similar results were reported by Akram et al., (2016) for number of pods per plant and days to maturity, Dubey et al., (2014) for number of pods per plant, plant height, number of seeds per pod, Abady et al., (2013) for plant height.

Table.1 List of genotypes along with pedigree included in the studies

\begin{tabular}{|c|c|c|}
\hline Sr.no. & Name of genotype & Pedigree \\
\hline 1 & BAUS-100 & JS 20-30/JS 335 \\
\hline 2 & CAUMS-1 & Selection from NRC 2012-6-3-1-4-3 \\
\hline 3 & DS-3109 & Pusa $12 / \mathrm{F} 4 \mathrm{C} 7-32$ \\
\hline 4 & DS-3110 & Pusa 12/F4C7-32 \\
\hline 5 & DSb-33 & DSb 21/JS 95-60 \\
\hline 6 & GJS-3 & Germ plasm line KB - 85 \\
\hline 7 & Himso-1688 & NRC 2007/B1-19 \\
\hline 8 & Himso-1689 & NRC 2008/G-1-12 \\
\hline 9 & JS-21-71 & JS 20-63/JS 95-60 \\
\hline 10 & JS-21-72 & SL 738/JS 95-60 \\
\hline 11 & KDS-1009 & AMS 99 33/EC 241780 \\
\hline 12 & KDS-1073 & JS 20-05/EC 241780 \\
\hline 13 & KS-113 & Selection from KS 103 \\
\hline 14 & MACS-1566 & RKS 24/NRC 55 \\
\hline 15 & MACS-1620 & RKS 25/NRC 55 \\
\hline 16 & NRC-138 & JS 97-52/NRC 107 \\
\hline 17 & NRC-139 & JS 97-52/NRC 101 \\
\hline 18 & NRC-146 & Selection from $6 \mathrm{~A}-34$ \\
\hline 19 & NRC-147 & Indigenous collection (IC 210) \\
\hline 20 & NRC-148 & NRC 7/AGS 191 \\
\hline 21 & NRCSL-2 & JS 335/SL 525 EDV of JS 335 \\
\hline 22 & PS-1634 & JS 9752/PS 1225 \\
\hline 23 & PS-1637 & JS 9752/PK 472 \\
\hline 24 & RSC-11-15 & JS 335/PS 1024 \\
\hline 25 & RSC-11-17 & JS 97-52/JS 93-05 \\
\hline 26 & RVS-2007-4 & RVS 2000-10/JS 95-60 \\
\hline 27 & RVS-2011-10 & JS -335/PK 1042 \\
\hline 28 & KS-103 & JS 335/EC 241780 \\
\hline 29 & KDS -726 & JS 9305/EC 241780 \\
\hline 30 & KDS - 753 & JS 9305/EC 241780 \\
\hline
\end{tabular}


Table.2 Genotypic (above diagonal) and phenotypic (below diagonal) correlation coefficient for eleven different characters of Soybean genotypes

\begin{tabular}{|c|c|c|c|c|c|c|c|c|c|c|c|}
\hline Observations & $\begin{array}{c}\text { Days to } \\
50 \% \\
\text { flowering }\end{array}$ & $\begin{array}{l}\text { Days to } \\
\text { maturity }\end{array}$ & $\begin{array}{c}\text { Plant } \\
\text { height } \\
\text { (cm) }\end{array}$ & $\begin{array}{c}\text { No. of } \\
\text { primary } \\
\text { branches/ } \\
\text { plant }\end{array}$ & $\begin{array}{l}\text { No. of } \\
\text { pods/ } \\
\text { plant }\end{array}$ & $\begin{array}{c}\text { No. of } \\
\text { seeds/ } \\
\text { pod }\end{array}$ & $\begin{array}{l}100 \text { seeds } \\
\text { weight }(\mathrm{g})\end{array}$ & $\begin{array}{l}\text { SPAD } \\
\text { Value }\end{array}$ & $\begin{array}{c}\text { Protein } \\
(\%)\end{array}$ & $\begin{array}{l}\text { Oil } \\
(\%)\end{array}$ & $\begin{array}{c}\text { Seed yield/ } \\
\text { plant (g) }\end{array}$ \\
\hline Days to $50 \%$ flowering & 1.00 & $0.73 * *$ & $0.77 * *$ & -0.08 & $0.17 *$ & $0.50 * *$ & $0.36 * *$ & $0.22 * *$ & -0.08 & $0.81 * *$ & $0.27 * *$ \\
\hline Days to maturity & $0.68 * *$ & 1.00 & $0.41 * *$ & $0.15^{*}$ & $-0.14 *$ & $0.31 * *$ & 0.02 & 0.06 & -0.001 & $1.08 * *$ & -0.06 \\
\hline Plant height (cm) & $0.72 * *$ & $0.38 * *$ & 1.00 & $0.13^{*}$ & $0.19 *$ & $0.33 * *$ & $0.35 * *$ & $0.20 *$ & -0.10 & $0.50 * *$ & $0.33 * *$ \\
\hline $\begin{array}{l}\text { No. of primary } \\
\text { branches/plant }\end{array}$ & -0.04 & 0.07 & 0.09 & 1.00 & $0.17 *$ & $-0.15^{*}$ & -0.09 & $0.24 * *$ & 0.05 & -0.004 & 0.04 \\
\hline No. of pods/plant & $0.16^{*}$ & $-0.13^{*}$ & $0.17 *$ & $0.13 *$ & 1.00 & $0.30 * *$ & -0.03 & $0.49 * *$ & 0.07 & 0.01 & $0.54 * *$ \\
\hline No. of seeds/pod & $0.48 * *$ & $0.27 * *$ & $0.29 * *$ & -0.11 & $0.27 * *$ & 1.00 & $0.19 *$ & $0.30 * *$ & 0.06 & $0.43 * *$ & $0.43 * *$ \\
\hline 100 seeds weight $(\mathrm{g})$ & $0.33 * *$ & -0.006 & $0.32 * *$ & -0.05 & -0.01 & $0.17 *$ & 1.00 & $0.26^{* *}$ & 0.001 & $0.54 * *$ & $0.41 * *$ \\
\hline SPAD Value & $0.17 *$ & 0.05 & $0.15^{*}$ & 0.06 & $0.42 * *$ & $0.24 *$ & $0.24 *$ & 1.00 & $0.14 *$ & $0.68 * *$ & $0.37 * *$ \\
\hline Protein (\%) & -0.09 & 0.02 & -0.03 & -0.02 & 0.06 & 0.05 & 0.03 & 0.06 & 1.00 & $0.50 * *$ & -0.02 \\
\hline Oil $(\%)$ & $0.26 * *$ & $0.33 * *$ & $0.16^{*}$ & -0.01 & -0.02 & 0.11 & 0.12 & $0.18^{*}$ & -0.05 & 1.00 & $0.14 *$ \\
\hline Seed yield/plant (g) & $0.27 * *$ & -0.06 & $0.31 * *$ & 0.02 & $0.51 * *$ & $0.39 * *$ & $0.35 * *$ & $0.32 * *$ & 0.001 & 0.01 & 1.00 \\
\hline
\end{tabular}

*Significant at $5 \%$ level, ** Significant at $1 \%$ level

Table.3 Direct and indirect effect of eight different yield and yield contributing characters of soybean

\begin{tabular}{|c|c|c|c|c|c|c|c|c|c|}
\hline Observations & $\begin{array}{c}\text { Days to } 50 \% \\
\text { flowering }\end{array}$ & $\begin{array}{l}\text { Days to } \\
\text { maturity }\end{array}$ & $\begin{array}{c}\text { Plant } \\
\text { height }(\mathrm{cm})\end{array}$ & $\begin{array}{c}\text { No. of primary } \\
\text { branches/ } \\
\text { plant }\end{array}$ & No. of pods/plant & $\begin{array}{c}\text { No. of } \\
\text { seeds/ } \\
\text { pod }\end{array}$ & $\begin{array}{l}100 \text { seeds } \\
\text { weight }(\mathrm{g})\end{array}$ & $\begin{array}{l}\text { SPAD } \\
\text { Value }\end{array}$ & $\begin{array}{c}\text { Seed yield/ } \\
\text { plant (g) }\end{array}$ \\
\hline Days to $50 \%$ flowering & -0.3126 & -0.2302 & -0.2431 & 0.0274 & -0.0556 & -0.1580 & -0.1154 & -0.0693 & 0.2733 \\
\hline Days to maturity & -0.0114 & -0.0155 & -0.0064 & -0.0024 & 0.0022 & -0.0049 & -0.0004 & -0.0010 & -0.0646 \\
\hline Plant height (cm) & 0.1642 & 0.0866 & 0.2111 & 0.0275 & 0.0406 & 0.0710 & 0.0753 & 0.0424 & 0.3331 \\
\hline $\begin{array}{l}\text { No. of primary } \\
\text { branches/plant }\end{array}$ & -0.0007 & 0.0012 & 0.0010 & 0.0080 & 0.0014 & -0.0012 & -0.0007 & 0.0020 & 0.0454 \\
\hline No. of pods/plant & 0.0940 & -0.0744 & 0.1017 & 0.0928 & 0.5291 & 0.1612 & -0.0192 & 0.2602 & 0.5433 \\
\hline No. of seeds/pod & 0.1456 & 0.0903 & 0.0969 & -0.0446 & 0.0878 & 0.2882 & 0.0567 & 0.0881 & 0.4317 \\
\hline 100 seeds weight $(\mathrm{g})$ & 0.1498 & 0.0113 & 0.1448 & -0.0372 & -0.0147 & 0.0799 & 0.4061 & 0.1082 & 0.4159 \\
\hline SPAD Value & -0.0183 & -0.0052 & -0.0166 & -0.0201 & -0.0407 & -0.0253 & -0.0220 & -0.0827 & 0.3773 \\
\hline
\end{tabular}

Residual effect $=0.6728$ 
Fig.1 Genotypic path diagram for seed yield

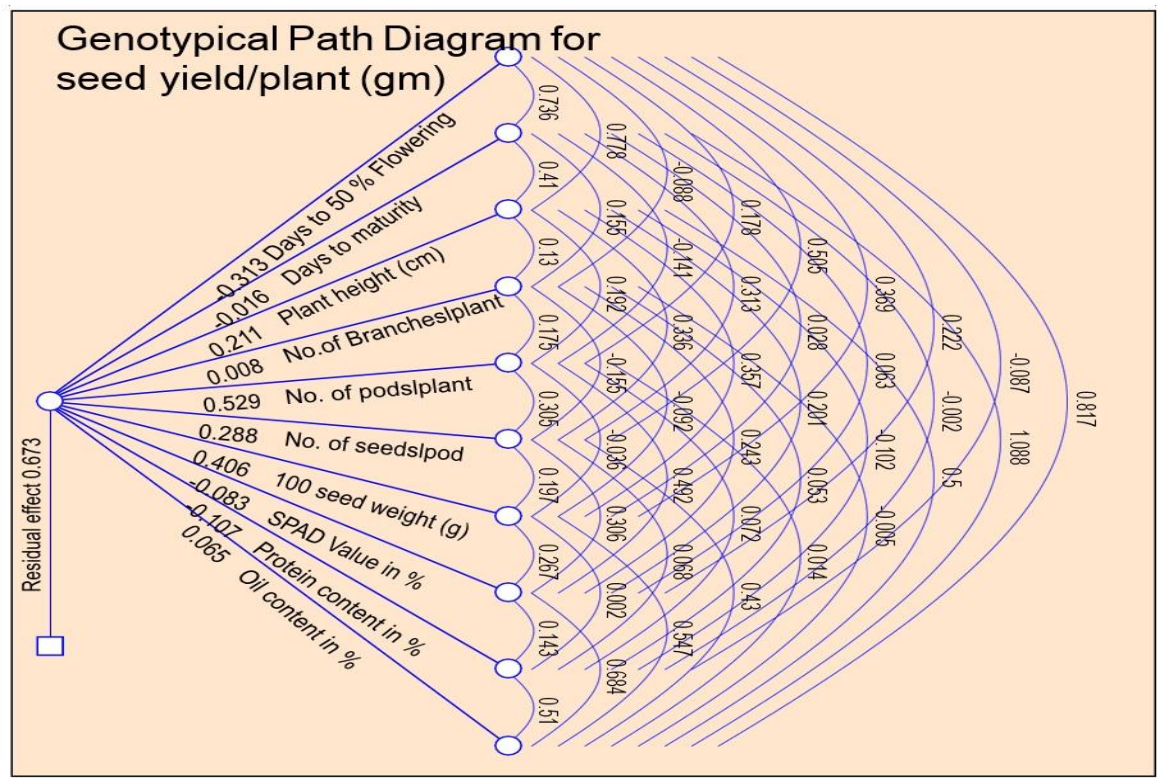

\section{Number of pods per plant}

The characters number of pods per plant recorded the maximum positive indirect effect of (0.2602) via SPAD value followed by the number of seeds per pod (0.1612), plant height (0.1017). A similar result was reported by Dubey et al., (2014) for the number of seeds per pod. Balla and Ibrahim (2017) for plant height. Malek et al., (2014) for pods per plant.

\section{Number of seeds per pod}

The character number of seeds per pod recorded the maximum positive indirect effect of (0.1456) via days to $50 \%$ flowering followed by plant height (0.0969), days to maturity(0.0903), SPAD value (0.0881), number of pods per plant (0.0878), 100 seed weight (0.0567). The maximum negative indirect effect of (-0.0446) was seen via the number of primary branches per plant. A similar result was reported by Dubey et al., (2014) for100 seed weight, Silva et al., (2014) for the number of pods per plant.

\section{0 seed weight $(g)$}

The character 100 seed weight recorded the maximum positive indirect effect of (0.1498) via days to $50 \%$ flowering followed by plant height (0.1448), SPAD value (0.1082), number of seeds per pod (0.0799), days to maturity (0.0113). The maximum negative indirect effect of $(-0.0147)$ was seen via the number of pods per plant followed by the number of primary branches per plant (0.0372). Similar results were reported by Akram et al., (2016) for days to 50 percent flowering and plant height, Dubey et al., (2014) number of seeds per pod.

\section{SPAD value}

The physiological character SPAD value recorded maximum negative indirect effect of $(-0.0052)$ was seen via days to maturity followed by plant height (-0.0166), days to 50 $\%$ flowering (-0.0183), number of primary branches per plant (-0.0201), 100 seed weight $(-0.0220)$, number of seed per pod $(-0.0253)$ and number of pod per plant (-0.0407). 
In the present investigation, the character number of pods per plant (0.5291) registered the maximum positive direct effect seed yield per plant followed by 100 seed weight (0.4061), number of seeds per pod (0.2882), plant height (0.2111). Days to $50 \%$ flowering recorded the highest negative direct effect of -0.3126 followed by SPAD value -0.0827 , days to maturity -0.0155 . Which confirmed with the finding of Balla and Ibrahim (2017) for the number of pods per plant and height of plant, Malek et al., (2014) for the number of pods per plant and 100 seed weight. Dubey et al., (2014) and Akram et al., (2016) for days to 50 percent flowering and days to maturity.

In conclusion the seed yield per plant was a significant and positive correlation with variables viz. number of pods per plant, number of seeds per pod, 100 seed weight, SPAD value, plant height, days to $50 \%$ flowering, and number of primary branches at genotypic level. The number of pods per plant (0.529) registered the maximum positive direct effect seed yield per plant followed by 100 seed weight (0.406), number of seeds per pod (0.288) and plant height (0.211). The number of primary branches per plant recorded the direct effect but low magnitude (0.008). Days to $50 \%$ flowering recorded the highest negative direct effect of -0.312 followed by SPAD value -0.082 and days to maturity -0.015 .

\section{References}

Abady, S., Merkeb, F. and Dilnesaw, Z. 2013. Heritability and path-coefficient analysis in soybean [Glycine max (L.) Merril] genotypes at Pawe, North Western Ethiopia. Journal of Environmental Science and Water Resources,2(8): 270276.

Aditya, J.P., Bhartiya, P. and Bhartiya, A. 2011. Genetic variability, Heritability and characters association for yield and component characters in Soybean. J. of
Central Agric., 12(1): 27-34.

Akram, S., Hussain, B. M. N., Bari, M. A. A., Buritt, D. J., Hussain M. A. 2016. Genetic variability and association analysis of soybean for yield and yield attributing traits. Plant Gene and Trait, 7(13):1-11.

Ali, A., Sher, A. K., Khan, E., Ali, N. and Izhar, H. 2015. Genetic studies among diverse soybean [Glycine max (L.) Merril].Genotypes for variability and correlation at Swat. International J. of Biosciences6(4): 165- 169.

Balla, M. Y. and Ibrahim, S. E. 2017. Genotypic Correlation and Path Coefficient Analysis of Soybean [Glycine $\max (\mathrm{L})$.$] For Yield and Its$ Components. Agri. Res.\& Tech. Open Access J.,7(3): 555-715.

Burton, C. W. and Devane, E. H. 1952. Estimating heritability in tall Festuca (Restucaarundinacae) from replicated clonal material. Agron. J. 45: 14761481.

Chandel, K. K., Patel, N. B. and Patel, J. B. 2014. Correlation Path Coefficients and Analysis in Soybean [Glycine $\max \mathrm{L}$. Merril]. An International electronic J., 3: 25-31.

Dewey, D. R. and Lu, K. H. 1959. A correlation and path coefficient analysis of component of crested wheat grass seed production. Agric. J.51(9): 515- 518.

Dubey, N., Avinashe, H. A., Shrivastava A. N. andJaiwar, S. 2014. Genetic variability, correlation and path analysis for yield and yield contributing characters in soybean (Glycine max L.). Electronic J. Plant Breeding, 6 (1): 318-325.

Faisal A. M., Qureshi, A.S., Ashraf, M. and Ghafoor, A. 2006. Glycine $\max$ (L.); Utilization of diverse germplasm for soybean yield improvement. International $J$. of Agriculture \& Biology, 6:815-819.

Ghodrati, G.R., Sekhavat, R., Mahmood, S.H. and Gholami, A. 2013. Evaluation of correlations and path analysis of components seed yield in soybean. 
International J. Agriculture,3(4):795800.

Iqbal Z., Arshad,M.,ashraf, M. R., Naeem, Faheem M. and Waheed, A.2010. Genetic divergence and correlation studies of soybean (Glycine max. (L.) Merril). Genotypes. Pakistan J. of Botany, 42(2): 971-976.

Jain, P.K. and Ramgiry. S.R.2000. Genetic diversity in Indian and abroad collection of soybean. Advanced Plant Science, 13(2): 487-490.

Khan, A., Farhatullah, Munir, I., Begum, S. and Ara, N. 2018.Genotypic comparison of determinate and indterminate soybean lines for yield and yield components. Pak. J. Bot., 50(1): 131-134.

Lenka, D. and Mishra, B.1973. Path coefficient analysis of yield in rice varieties. Indian J. of Agricultural Sciences, 43:376 379.

Mahbub, M. M., Mamunur R. M., Hossain, M. S., Mahmud, F. and Mir, M. M. 2015. Genetic Variability, Correlation and Path Analysis for Yield and Yield Components in Soybean. AmericanEurasian J. of Agricultural \& Environmental Sciences, 15(2): 231236.

Mahbub, M. and Shirazy, B. J. 2016. Evaluation of Genetic Diversity in Different Genotypes of Soybean (Glycine max (L.) Merril). American J. of Plant Biology, 1(1): 24-29.

Malek, M. A., Mohd, Y., Rafii, Afroz, Nath, U. J. and Monjurul, M. M. 2014. Morphological Characterization and
Assessment of Genetic Variability, Character Association, and Divergence in Soybean Mutants. The Scientific World J. 14: 1-12.

Machikowa, T. and Laosuwan, P. 2011. Path coefficient analysis for yield of early maturing soybean. J. of Science and Technology, 33(4): 365-368.

Ngon, T. T., Van, K., Kim, M. Y. and Lee, S. H. 2006. Genetic variation in flowering time and maturity and its relationship among agronomic characters in soybean. Korean Crop Science, 51(2): 163-168.

Panse, V.G. and P.V. Sukhatme. 1957. Statistical methods for agricultural workers. Indian Council of Agriculture Research, New Delhi. pp. 359.

Rajanna, M. P., Viswanatha, S. R., Kulkarni, R. S. and Ramesh, S. 2000. Genetic variability in soybean (Glycine $\max (\mathrm{L}$.) Merril). Crop Research (Hisar), 20(1): 108-112.

Salimi, S. and Moradi, S. 2012. Effect the correlation, regression and path analysis in soybean genotypes [Glycine $\max (\mathrm{L}$.) Merril] under moisture and normal condition. International Journal of Agronomy and Plant Production,3(10): $447-454$.

Silva, A. F., Sediyama, T., Silva, F. S. C. and Ferreira, L. V. 2014. Correlation and Path analysis of Soybean Yield Components. International J. Plant Animal and Environmental Sciences, 5(1): 175-179.

\section{How to cite this article:}

Pawar, M. G., S. B. Chaudhary, V. S. Pawar and Chavan, S. B. 2020. Correlation Coefficient and Path Analysis Study in Different Soybean Genotypes Based on Yield and Yield Contributing Traits. Int.J.Curr.Microbiol.App.Sci. 9(09): 434-444. doi: https://doi.org/10.20546/ijcmas.2020.909.055 